\title{
Mannitol Measurement
}

National Cancer Institute

\section{Source}

National Cancer Institute. Mannitol Measurement. NCI Thesaurus. Code C154742.

The determination of the amount of mannitol present in a sample. 